\title{
Research on current situation and countermeasures of communication of vocational college students' Network political information
}

\author{
Xiu-li LI ${ }^{1, a}$ \\ ${ }^{1}$ The Branch of Jilin Normal University, siping 136000,China \\ axiuliLI1026@yeah.net
}

Keywords: Higher vocational colleges; ideological and political; present situation; Countermeasures

\begin{abstract}
The rapid development of higher vocational education effectively promoted the economic and social development, meeting the needs of the people and making a contribution for the realization of the popularization of higher education. In the network information age, the ideological and political work in higher vocational colleges are faced with many new situations and challenges. This paper analyzes the ideological and moral qualities of vocational students, and actively explore effective ways of Ideological and political education in Higher Vocational colleges.
\end{abstract}

\section{Introduction}

The rapid popularization of network has two implications, on the one hand, network expands new channels, new methods and new means of Ideological and political work in higher vocational colleges, helping to improve the coverage and influence of the ideological and political work and bringing the new opportunity for strengthening and improving the ideological and political work in Higher Vocational colleges. On the other hand, because of quick and wide spread of all kinds of wrong ideological, point of view and harmful information through the network, with immature ideological views of minority of students, part of students trust in non-mainstream and even radical, false information in the network more than formal education, which has caused the occurrence of unethical or even illegal behavior. It brings the giants of the difficulties and challenges to the ideological political work in higher vocational colleges.

As workers of vocational school ideological and political, we must pay great attention to the opportunities and challenges of ideological and political education the Internet brings. It is our duties to actively explore to improve and strengthen the ideological and political work with Internet and overcome the adverse effects to develop political education positively, strengthen the management and draw on advantages and avoid disadvantages of Internet”.

\section{The meaning and function of network carrier of ideological and political education in Colleges and Universities}

\section{Meaning of ideological political education of university network carrier}

"Carrier" means that something can transfer energy in other substances. But now, "carrier" have entered the field of social science research and be widely used. Carrier plays an important role for information transfer and inheritance. The carrier of university's ideological and political education is the content and information bearing of ideological and political education material, connecting the educators and those who were educated.

\section{Function of ideological political education of university network carrier}

The carrier of college ideological and political education with network has many characteristics such as bearing, selectivity, controllability, permeability,interactivity and openness. College ideological and political education in network receives the information of these ideological political education penetrated in the network carrier. People can select different information the really need even if they are not in the same place, which make participants have enough initiative. People can achieve the purpose of Ideological and Political Education through cooperation and information exchanges, which can give students a platform to highlight their personality. In such an open 
system, ideological and political education can advance with the times and be injected new information with the changes of the times.

\section{Use the network for the favorable conditions for teaching}

The rapid development of the Internet has brought many favorable conditions for the ideological and political education, as shown below:

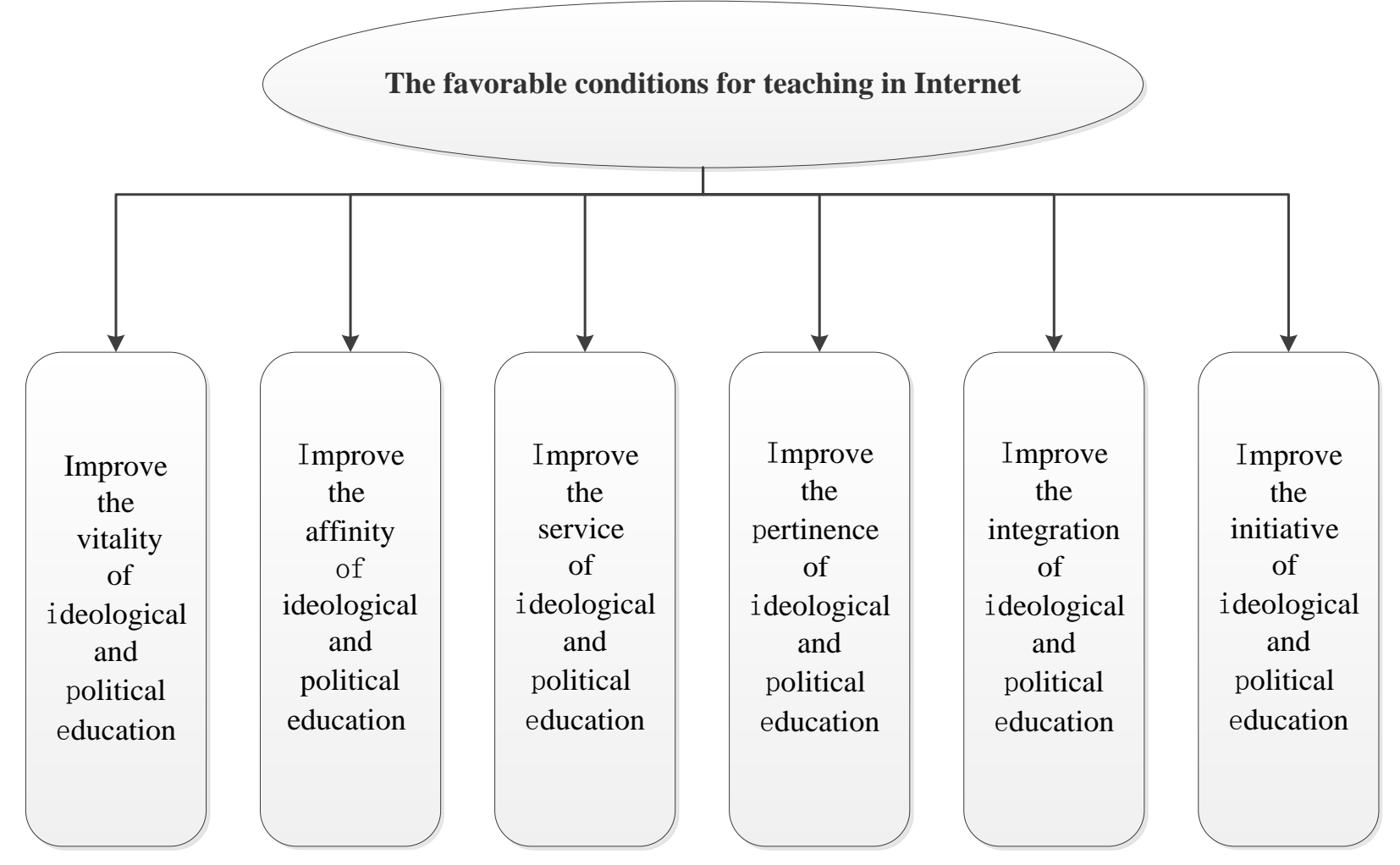

Figure1. The favorable conditions for teaching in Internet

As teachers of Ideological and Political Course in higher vocational school, we should do more to teach based on network, according to the figure above, we obviously should:

i.Improve the vitality of ideological political education;

ii.Improve the affinity of ideological and political education;

iii.Improve the service of ideological and political education;

iv.Improve the pertinence of ideological and political education;

v.Improve the integration of ideological and political education;

vi.Improve the initiative of ideological and political education.

They all are based on the correct usage of the Internet. At the same time, the educators also need to over come the adverse effects for teaching in Internet.

\section{Overcome the adverse effects for teaching in Internet}

Bad information is easy to cause the students' ideological confusion and shake students' political beliefs, values, legal consciousness and moral standards, even cause some students committing crimes. Ideological and political workers must seriously study the mutual influence of Internet, strengthen the management of the information, actively promote the social theme of spirit and strive to eliminate all kinds of bad online information based on the principle "Drawing on the advantages and avoiding disadvantages". 


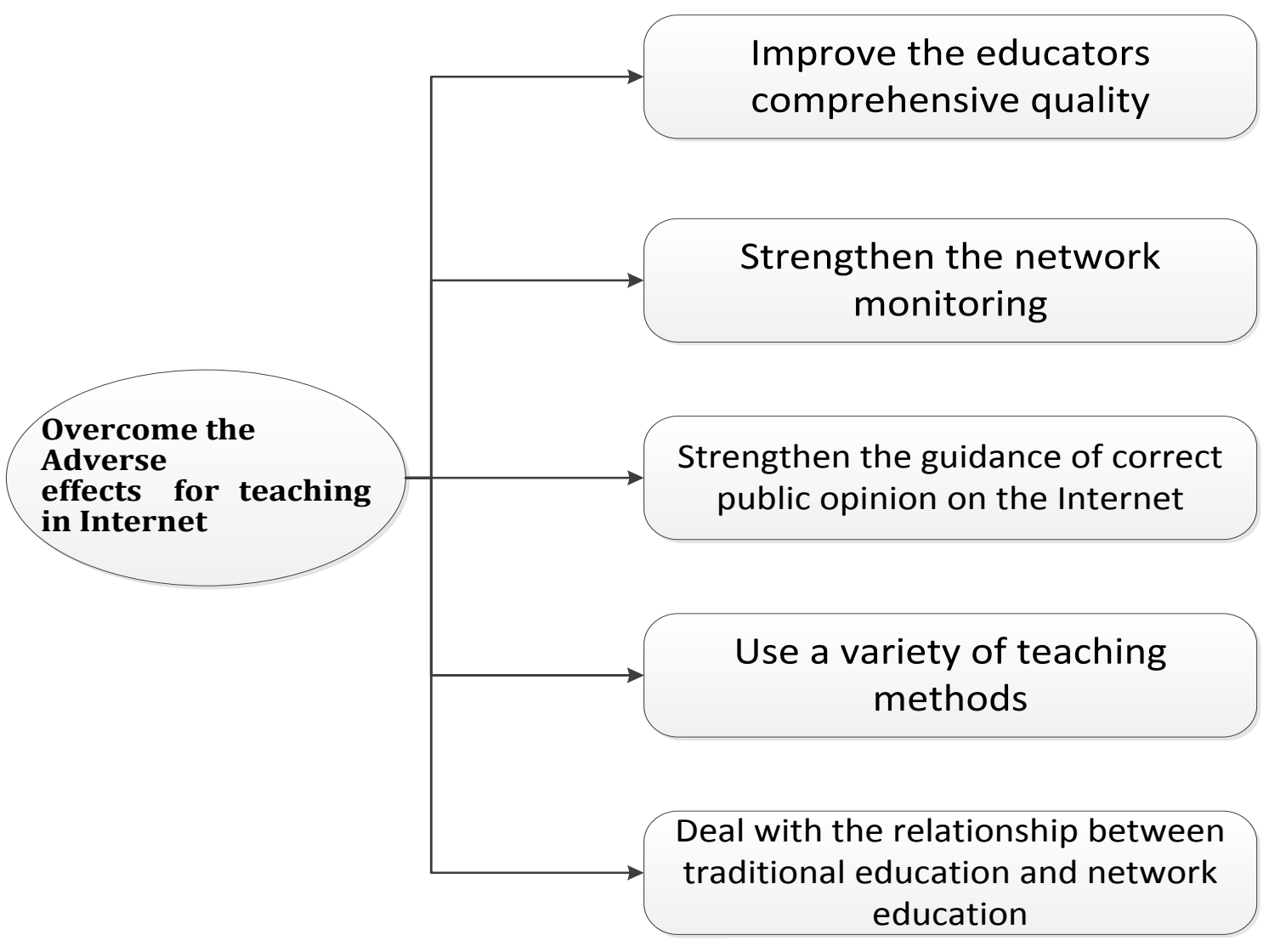

Figure2. The ways to overcome the adverse effects for teaching in Internet

The measures of correct guidance of new carrier construction of ideological and political education

\begin{abstract}
Strengthen national supervision on source of Ideological and political education information from network carrier

The network carrier of ideological and political education plays an important role for the stability of our political order. but some agitation for secession such as "Taiwan independence", "Tibet independence" and other remarks can also be seen in the network. If the wanton dissemination of these remarks online be indulged, it is certainly not conducive to social stability. Therefore, it is particularly important to strengthen the monitoring of the network information in our country. Only eliminate unfavorable rumors from the source can the social fundamental shake caused by unfavorable rumors be control in the lowest range.
\end{abstract}

Establish the college students' correct views, teach them to learn to distinguish between truth and false

People in the age of College Students has an unstable state of philosophy,values and world view. The school, as an educational institution, has the indelible responsibility to guide students to set up correct views. In 2007, Tsinghua University held "Beijing college students network civilization behavior forum"; Peking University, North China Electric Power University and other colleges and universities also actively promote the "green activity project network of civilization", attracting many students to actively participate in. The school provides support during the event. Through these interesting activities, students can participate in them to improve their ability to distinguish right from wrong and develop their own independent judgment of network information.

Diversify the interactive channel for ideological and political education carrier, increasing its lively and interesting

As educators, we can provide a part for the student in the political education network course, which can give them a new chance to increase the interactive channels between teachers and students and 
improve the innovation of these students. AT the same time, teachers can open "discussion room" or "chat room" outside the classes to give students a platform to express their own opinions on the thought of class. Through this method, teachers and students can be in an equal status, giving full play to the interaction. Teachers can also open column for some excellent ideas, which can better encourage students to join the discussion and stimulate their initiative.

\section{Conclusion}

The new carrier of ideological and political education in colleges and universities in the network age is a trend in the current situation. Colleges and universities should grasp and take advantages of this favourable trend scientifically, gradually build up the new carrier of their own ideological and political education based on their own actual situation, which can spread the right ideal and faith in a better way.

\section{Acknowledgements}

"Five-year plan" task "harmonious moral education research and experiment" ShiYanJiao corpus name: moral education reform and practice research.

\section{References}

[1] Jufen Z. A survey of the English learning situations of the non-English major freshmen [J][J]. Foreign Language World, 2003, 1: 007.

[2] ZHOU W, GUO G. Self-efficacy: The Conception, Theory and Applications [J][J]. Journal of Renmin University of China, 2006, 1: 013.

[3] Zhisu W. Several View about the Course-Designing of University Physical Education [J][J]. SPORTS \& SCIENCE, 1999, 2: 013.

[4] LI Y, TIAN X. A Research on the Relations Between Academic Self-concept and Academic Achievement for Junior Middle School Students [J][J]. Journal of Hubei Institute For Nationalities, 2002, 3: 017.

[5] Zhiqiang L. Analysis of Present Factors influencing Chinese People's Sports Consumption Mentality and Research on Countermeasures $[\mathrm{J}][\mathrm{J}]$. Journal of Beijing University of Physical Education, 1999, 3: 004. 